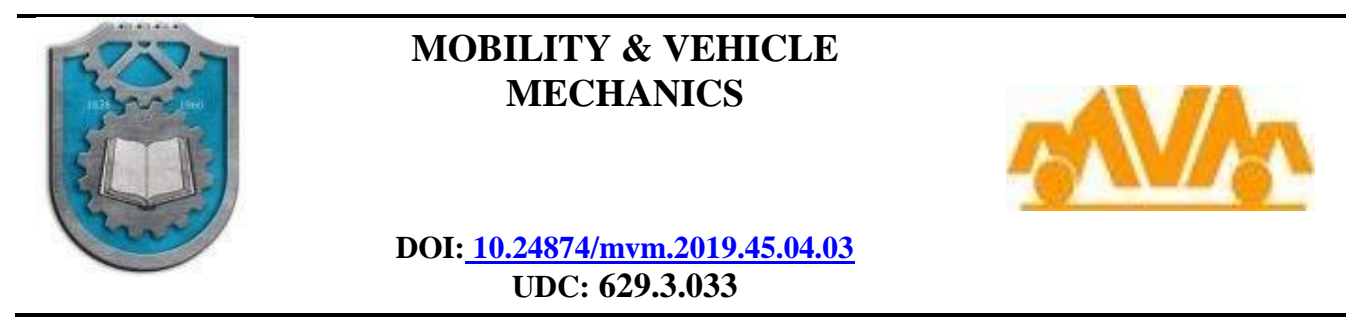

\title{
WILL ELECTRIC MOTOR SUBSTITUTE INTERNAL COMBUSTION ENGINE?
}

\author{
Dušan Gruden $^{1 *}$
}

Received in September $2018 \quad$ Accepted in October 2018

\section{RESEARCH ARTICLE}

\begin{abstract}
The first transportation means driven by a DC electric motor was a sixpassenger boat. Ground vehicles with electric drive have also a longer history than vehicles with IC engines. At the beginning of the 20th century, there were more cars driven by electric motors then those driven by IC engines. During the last 100 years, there have been many attempts to replace the IC engine with supposedly better power units. Experiments with electric vehicles were repeatedly performed. Around 1.1 million electric vehicles or about $0.12 \%$ of 947 million of passenger vehicles is used in the world traffic today. In terms of $\mathrm{CO} 2$ emissions, electric cars have an environmental advantage after 2 to 4 years of use, only if the electricity for their charging is created by regenerative sources: water, wind, solar energy, high and low tides or nuclear energy (as in France). In China and Germany, where the largest part of the electricity is produced in the coal or gas power plants, the $\mathrm{CO} 2$ emissions created by electric cars are significantly higher than those created by cars with IC engines are. It is the opinion of many experts, that vehicles with combined drive via an electric motor and a single, relatively small and optimized IC engine (so-called hybrid drive), present the best solution passenger cars in the future, especially in terms of reduction of toxic emission in the cities, as well as in reduction of fossil fuels consumption. The conclusion of this analysis of electric drives for motor vehicles, can only state the same as it repeats for over half a century: "The piston IC engines will be substituted by the better powertrains during the following 10 to 15 years and the existing oil reserves will be spent in the next 30 to 40 years!"
\end{abstract}

KEY WORDS: fuel cells, hybrid vehicles, electric vehicles, ecological fuels, IC engine

C 2019 Published by University of Kragujevac, Faculty of Engineering

${ }^{1}$ Dušan Gruden, PhD prof., Technical University of Vienna, Karlsplatz, 13, 1040 Vienna, Austria, former director of Engine development and Sector for ecology end energy at Porsche, Stuttgart, gruden@yudit.de (*Corresponding author)

Mobility \& Vehicle Mechanics, Vol. 45, No. 4, (2019), pp 19-31 


\section{DA LI ĆE ELEKTROMOTOR ZAMENITI MOTOR SA UNUTRAŠNJIM SAGOREVANJEM?}

REZIME: Prvo prevozno sredstvo pogonjeno jednosmernim električnim motorom bio je čamac sa šest putnika. Kopnena vozila sa električnim pogonom takođe imaju dužu istoriju od vozila sa motorima sa unutrašnjim sagorevanjem. Početkom 20. veka bilo je više automobila koje pokreću električni motori, nego onih koje pokreću motori sa unutrašnjim sagorevanjem. Tokom poslednjih 100 godina bilo je mnogo pokušaja zamene motora sa unutrašnjim sagorevanjem navodno boljim agregatima. Eksperimenti sa električnim vozilima su više puta izvedeni. U svetskom saobraćaju danas se koristi oko 1,1 milion električnih vozila ili oko $0,12 \%$ od 947 miliona putničkih vozila. Što se tiče emisije $\mathrm{CO}_{2}$, električni automobili imaju ekološku prednost nakon 2 do 4 godine korišćenja, samo ako se električna energija za njihovo punjenje stvara iz regenerativnih izvora: vode, vetra, solarne energije, visokih i niskih oseka ili nuklearne energije (kao u Francuskoj). U Kini i Nemačkoj, gde se najveći deo električne energije proizvodi u elektranama na ugalj ili gas, emisije $\mathrm{CO}_{2}$ koje stvaraju električni automobili značajno su veće od onih koje stvaraju automobili sa motorima sa unutrašnjim sagorevanjem. Mišljenje mnogih stručnjaka je da vozila sa kombinovanim pogonom preko elektromotora i jednim, relativno malim i optimizovanim motorom sa unutrašnjim sagorevanjem (tzv. Hibridni pogon) predstavljaju najbolje rešenje putničkih automobila u budućnosti, posebno u pogledu smanjenja toksične emisije u gradovima, kao i smanjenju potrošnje fosilnih goriva. Zaključak ove analize električnih pogona za motorna vozila može reći samo ono što se ponavlja više od pola veka: „Klipni motori sa unutrašnjim sagorevanjem biće zamenjeni boljim pogonskim sklopovima tokom sledećih 10 do 15 godina i postojećim rezervama nafte biće potrošeni u narednih 30 do 40 godina!"

KLJUČNE REČI: gorive ćelije, hibridna vozila, električna vozila, ekološka goriva, motor sa unutrašnjim sagorevanjem 


\section{WILL ELECTRIC MOTOR SUBSTITUTE INTERNAL COMBUSTION ENGINE?}

\section{Dušan Gruden}

\section{INTRODUCTION}

In the world, and particularly in Europe, an intense discussion is being lead today about the need to forbid the use of internal combustion engine (IC engine) because it, allegedly, has only negative consequences on human environment. Representatives of the Green party in Germany are seeking a ban on the IC engine from the year 2030 in their program, while their counterparts from the Social-democratic party demand this ban from 2040. French writer and philosopher Andre Marlo wrote: "Who wants to predict the future, must first go through the past"!

\section{SHORT HISTORY OF ELECTRIC VEHICLES}

The first transportation means driven by a DC electric motor was a six-passenger boat, patented by Morris Herman von Jacobi in 1838, trying his own boat on the Neva in Saint Petersburg, Russia [1]. Ground vehicles with electric drive have also a longer history than vehicles with IC engines. As early as 1881 , five years before the first motor vehicles arrived, which are attributed to Daimler and Benz in Germany, an Englishman, Gustav Truve, have built in the electric drive on a tricycle. In 1898, Gaston Šezelup-Labat laid the first car speed record. With a car with electric drive, he achieved a speed of $63.12 \mathrm{~km} / \mathrm{h}$. In 1890, the carriage maker from Vienna, Ludwig Lonner, gave an order to the young engineer Ferdinand Porsche to develop a cab, which would be powered by the electric motor. At the world exhibition in Paris in 1900, Porsche and Loner presented their patent: vehicle driven by electric motors built-in on its wheels, so that each wheel had its

own drive, Figure 1.

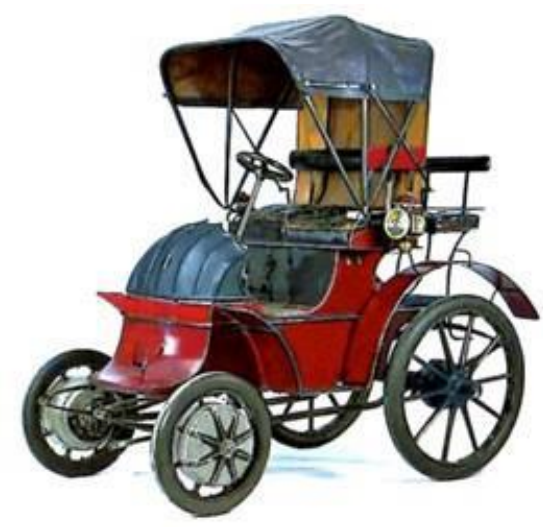

Figure 1. Loner-Porsche electric vehicle at the World exhibition in Paris in 1900

At the beginning of the 20th century, there were more cars driven by electric motors then those driven by IC engines. In that time, the forecasts for the future of the cars with electric drives were significantly more optimistic than for cars with IC engines. Back in 1910, over $30 \%$ of cars in the traffic in the US were electric cars. Accumulation (storage) of electricity 
in these cars was carried out exclusively in so-called lead $(\mathrm{Pb})$ accumulators - batteries. Their great weight, for any larger energy capacity of battery, and the long time it takes to charge the battery, were the biggest shortcomings of those cars. At that time, passenger vehicles with electric motors could develop speeds of around $100 \mathrm{~km} / \mathrm{h}$ and had a range of about 70 to $100 \mathrm{~km}$. The rapid development of IC engines, especially after the invention of the electric starters for engines, where the lead electric car battery as a power source for the start-up have been applied until today, has begun to suppress electrical drives, first of all in passenger vehicles. The culmination of application of electric drives, especially in the field of freight transport, was reached between 1920 and 1930. To minimize the main disadvantage of electric vehicles - their small driving radius, so called hybrid drives or vehicle drives with two engines - electric motor, consuming the electric power from lead batteries, and IC engine, which drives a generator to produce electricity for charging the battery, were offered at the beginning of the 20th century, Figure 2. The first hybrid car of that time was a Ford (1912).

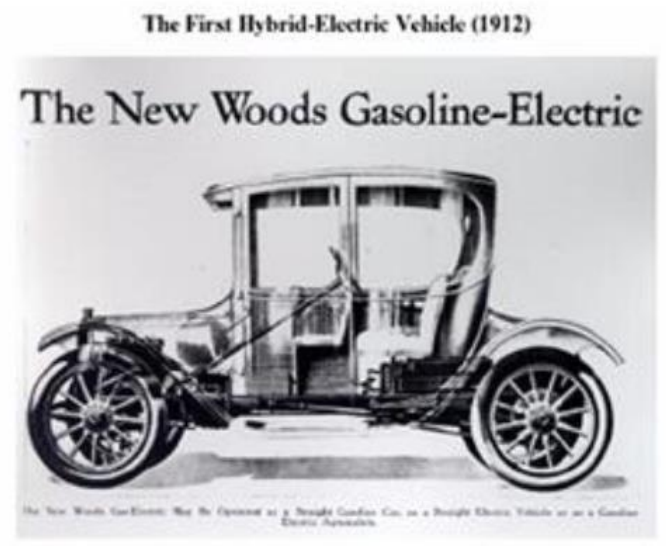

Figure 2. The first hybrid vehicle

High production costs for these vehicles prevented their wider application. The electricity, similar to the heat, has a feature that it has to be consumed the second when produced, because its storage is not simple, but very difficult and complicated. In vehicles which are directly connected to a source of electricity, like in rail transportation, trams and trolley buses, electrical drives are established for decades, with all their advantages.

\section{STATE OF THE ART IN DEVELOPMENT OF VEHICLE POWER UNITS}

Since 1920s, until today, piston internal combustion engines (IC engines) have become the undisputed drive unit, not only for passenger cars and freight vehicles, but also for a wide range of other different applications. The IC engine owes this wide distribution to its characteristic that it uses one of the biggest and the cheapest energy sources of the planet Earth, namely oil, with greater efficiency than other power units. During the last 100 years, there have been many attempts to replace the IC engine with supposedly better power units. Experiments with electric vehicles were repeatedly performed. From the 1980s, the attempts in Mendrizi (Switzerland), Berlin (FR Germany), La Rošelu (France) and Amsterdam (the Netherlands) were well known. In the early 1990s, extensive testing of electric cars were conducted on Reagan island in the Baltic Sea (FR Germany), with always the same conclusions: main problems are the storage, accumulation of electric power in batteries, 
small driving radius of vehicles and their high production costs. Although different batteries like $\mathrm{NiCd}$ (Nickel-Cadmium), $\mathrm{NaCl}$ (Sodium chloride), $\mathrm{NaS}$ (Sodium-Sulfur) and $\mathrm{NaNi}$ (Sodium-Nickel) were tested at that time, the lead $(\mathrm{Pb})$ battery has always been the winner, despite all its faults. Its energy capacity is around $70 \mathrm{Wh} / \mathrm{kg}$. It takes a lead battery of 3,000 1 of volume and $6.5 \mathrm{t}$ of weight for the same amount of energy as in a reservoir for gasoline of 701 (gasoline 12,000 Wh/kg). The modern lithium-ion batteries (Li-Ion) have an energy capacity of approximately 100 to $250 \mathrm{Wh} / \mathrm{kg}(250$ to $620 \mathrm{Wh} / \mathrm{l})$, that is, in order to replace the energy amount in 701 of gasoline, they need to have the volume between 400 and 1,000 1 and the weight of 0.4 to 2.0 t, Figure 3 .
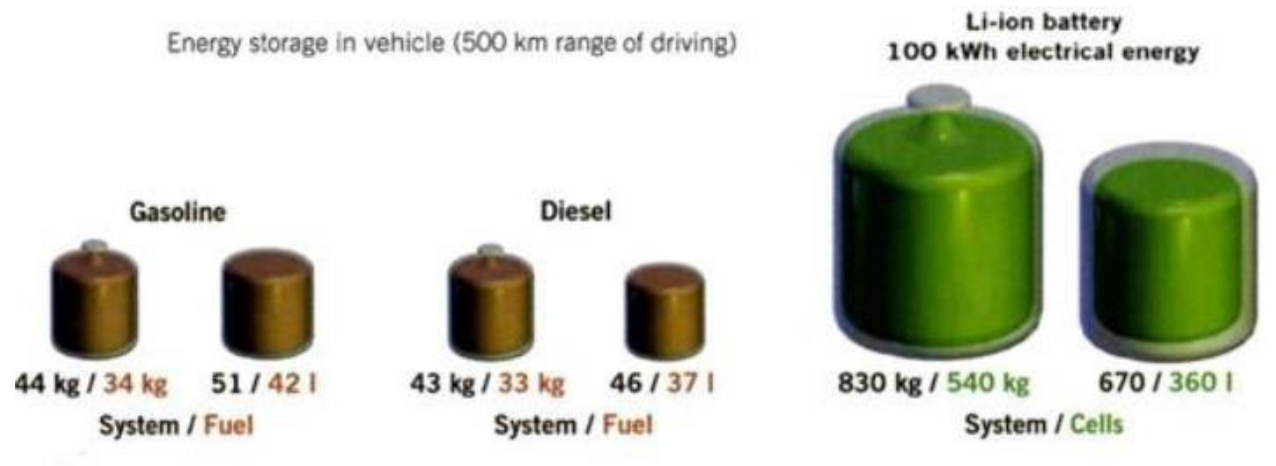

Figure 3. Energy needed for $500 \mathrm{~km}$ range of driving

Whether electric vehicles would succeed in this new attempt to break through to a large serial production and replace piston IC engines depends on the further development of accumulator - battery, its production cost and energy charging speed. Until now, passenger vehicles with electric drives have been produced in relatively small numbers. Around 1.1 million electric vehicles or about $0.12 \%$ of 947 million of passenger vehicles is used in the world traffic today. The share of these vehicles in the traffic in the USA is about $0.76 \%$ and in Germany about $0.38 \%$. These numbers suggest that, until now, the use of the electric vehicles was limited to a small area of application, first in small distance traffic, in the city traffic and as a second or a third vehicle in the household. In the future, vehicles with electric drives would have to satisfy the demands, as complete family vehicles, able to cover larger distances. The key problem of all electric cars is their driving radius. For fast covering of larger distance, not only a distance travelled with one battery charge is important, but also the time it takes to charge the empty battery. Today's standard battery charging is carried out with relatively low or medium-sized power, with the power supply voltage of $110 \mathrm{~V}$ or 220 $\mathrm{V}$, and it lasts several hours, similarly to charging Li-ion batteries in mobile phones or laptops. These vehicles should always be charged, when they are not used for a long time, for example at the parking lots or at homes, in garages. To increase the speed of charging to approximate time needed to refuel the vehicles with the IC engines, systems with high power and voltage of $800 \mathrm{~V}$ to $1,000 \mathrm{~V}$ are being developed, which causes a substantial increase in investment for the design of infrastructure. All consumers of energy in the electric vehicle are supplied with energy contained in the battery. Thus, the driving radius of vehicles with electric drive is greatly influenced by the weather conditions in which the ride takes place (day, night, rain, snow...). Vehicle's air-conditioning, especially the heating of electric vehicles, can significantly reduce their driving radius, Figure 4. 


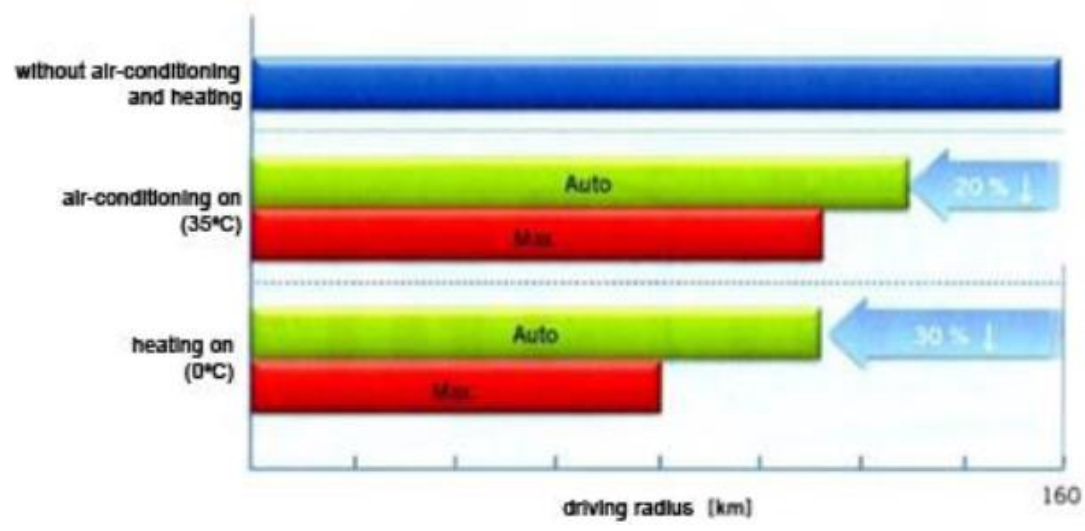

Figure 4. Driving radius of electric vehicles with air-conditioning and heating turned on

The typical battery of the electric vehicle consists of more than 100 cells. In Tesla S car, the battery consists of 16 modules with 7,104 Li-ion cells. It takes only a single cell not to work and the whole system has to be changed. All batteries have certain temperature areas in which they can work optimally. These operating temperatures affect the capacity of the battery (and hence the driving radius), as well as battery life. That is why the so-called thermal management of the batteries is very important. For Li-ion batteries, the optimum operating temperatures lie between $20{ }^{\circ} \mathrm{C}$ and $40{ }^{\circ} \mathrm{C}$. It is often emphasized, that the ecological advantage of electric cars is that they do not emit toxic emissions during their operation. That is true if only those emissions that arise on the path from the battery to the car's wheels are considered (so-called "tank-to-wheel" analysis). However, if one looks at the overall ecological balance of electrical cars, from its construction until the end of his lifetime (the "Life cycle assessment"), then the environmental image of electric cars looks different. While around $5 \mathrm{t}$ of $\mathrm{CO}_{2}$ emissions arises during the production of one middle class motor vehicle, this emission doubles during the production of an electric car, Figure 5 [4].

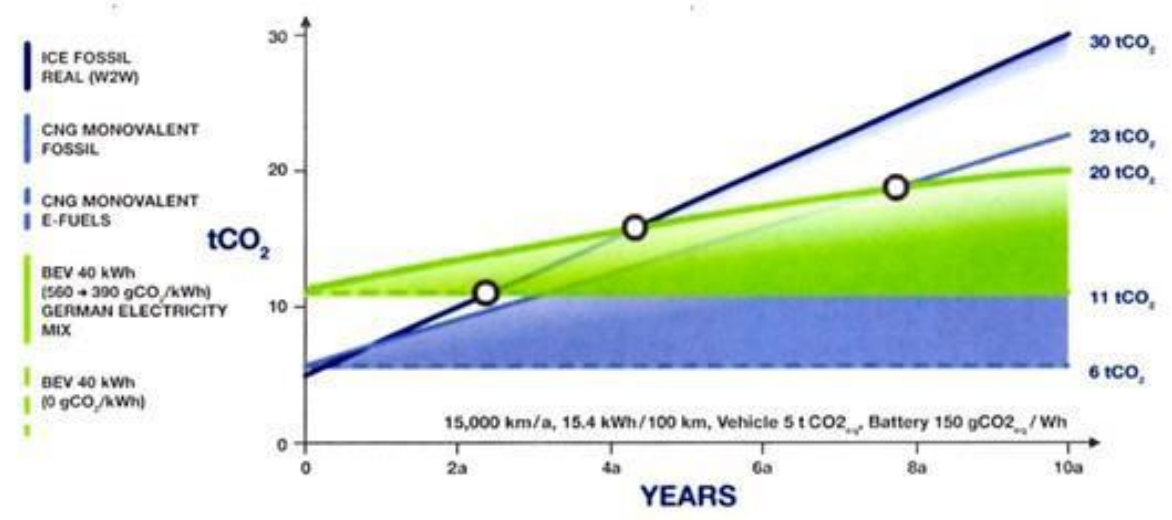

Figure 5. LCA (Life Cycle Assessment) of $\mathrm{CO}_{2}$ emission (ICE - Internal combustion engine, $\mathrm{CNG}$ - compressed natural gas, E-Fuels - ecological fuels, BEV - electric vehicles) 
In terms of $\mathrm{CO} 2$ emissions, electric cars have an environmental advantage after 2 to 4 years of use, only if the electricity for their charging is created by regenerative sources: water, wind, solar energy, high and low tides or nuclear energy (as in France). In China and Germany, where the largest part of the electricity is produced in the coal or gas power plants, the $\mathrm{CO} 2$ emissions created by electric cars are significantly higher than those created by cars with IC engines are, Figure 6.

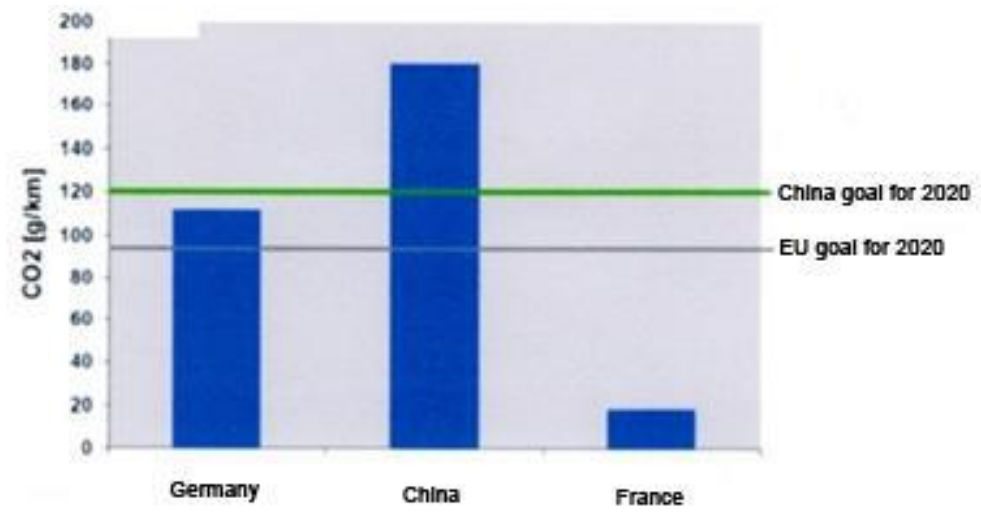

Figure 6. $\mathrm{CO}_{2}$ emissions of electric car depending on type of electricity production

Today's electric cars with Li-ion batteries cannot meet the European regulations on the recycling of cars. At the end of their lifetime, the passenger cars manufactured by 2015 must prove that $95 \%$ of their weight can be re-used or recycled. Only $5 \%$ of the vehicle's weight may be deposited on the landfill. With modern electric cars, the weight of Li-ion batteries is approximately $25 \%$ to $30 \%$ of the vehicle's weight. Until today, solutions for economic reasonable recycling of these batteries have not been found. Also in the area of public and freight transport, there are visible efforts to replace IC motors with electric drives. This drive long ago dominates where there is a direct contact between the transport means and the electricity sources (railways, trams, trolley buses). In some countries, the city transport also contains buses with electric drives, Figure 7. The batteries for these vehicles are charged at terminals over trolleys similar to those on trams or trolley buses.

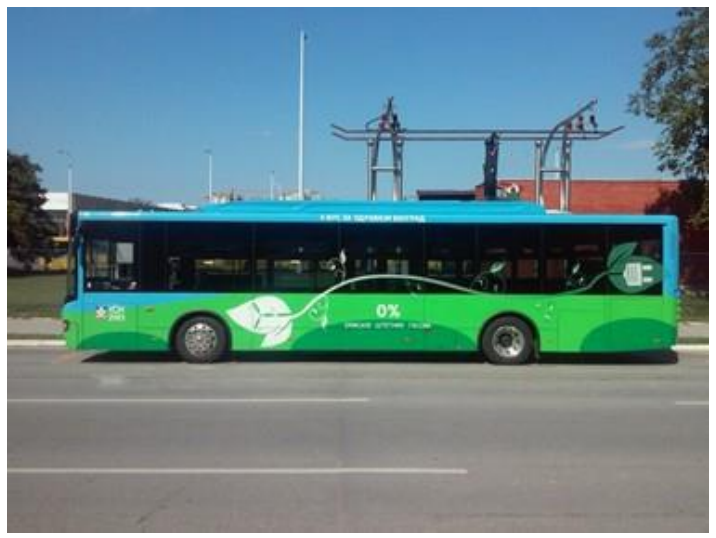

Figure 7. Electric bus in Belgrade traffic 
German industry has suspended work on these projects, because the weight of the batteries is to large, for slightly larger distances that the vehicle would have to pass.

\subsection{Hybrid vehicles}

One of the biggest disadvantages of electric cars - their relatively small driving radius compared to the cars powered by IC engines, has led to re-development of so-called hybrid cars. With these cars, the features and benefits of the electric drives combine with the positive features of the IC engines. It is the opinion of many experts, that vehicles with combined drive via an electric motor and a single, relatively small and optimized IC engine (so-called hybrid drive), present the best solution passenger cars in the future, especially in terms of reduction of toxic emission in the cities, as well as in reduction of fossil fuels consumption. For years, the hybrid vehicles have become the subjects of huge series production. Out of all the different possible combinations between the electric motors and the IC engines, it looks like a so-called "plug-in hybrid" is the most attractive today. Statistically, one car travels a distance of $30 \mathrm{~km}$ to $50 \mathrm{~km}$ daily. The goal of the development of the "plug-in" hybrids is to cover the daily distance in everyday traffic with electric drive, because the battery is dimensioned in such a way, that the vehicle can cross this distance. The battery of these vehicles is charged over the normal power supply network (plug-in), at home, or in the workplace. A relatively small IC engine is used in the case when the battery runs out of power, in order to run the generator for the production of electric power and enable the travel over the larger distance. About the half of the so-called electric vehicles in the world are "plug-in" hybrids. How big an advantage the hybrid drive offers compared to pure electric or IC engine drive, can be shown on the example of the Porsche 919 hybrid vehicle [8]. This vehicle have been winning the race on the famous 24 hours of Le Mans race for three years in a row, Figure 8.

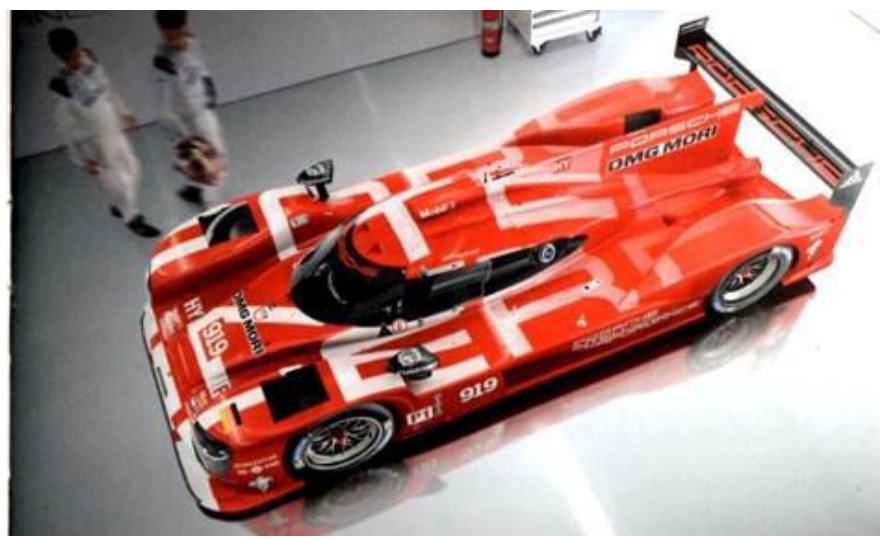

Figure 8. The winner of "The 24 hours of Le Mans" race in 2015, 2016 and 2017: Porsche 919 Hybrid

In the area of freight or commercial vehicles and buses, there are also extensive tests with hybrid drives (MAN, Volvo, Iveco).

\subsection{Electric drives in water traffic}

A historical example of the first vehicle with electric drive from 1838 shows that the electric drive is not connected just to the road vehicles on wheels. For more than 100 years, all 
submarines have electric (hybrid) drives. After successful deployment of electrical drives on the road vehicles, there are more and more attempts to apply this drive on vehicles in water transport. On many Alpine lakes in Austria, Slovenia, Switzerland and Germany, where it is prohibited to use the boats and the ships with IC engines, vessels with electric drives and with heavy lead batteries are used for decades. New attempts to use electric drives for the ships are associated with efforts to reduce the toxic emissions from exhaust gases of ship engines, especially in large ports, where the emission significantly exceeds the exhaust emission of passenger vehicles. Application of two-stroke diesel engines and the bad quality of the relatively cheap fuels for these engines (heavy oil fractions, mazut) lead to high emissions of sulphur dioxides $\left(\mathrm{SO}_{2}\right)$, nitrogen oxides $\left(\mathrm{NO}_{\mathrm{x}}\right)$ and particulate matter $(\mathrm{PM})$ with these engines. The most attractive electrical drive is for ferries, where the distance between the two ports is not large. The most famous ferry with electric drive is Norwegian ship "Ampera". Its battery pack weighs $10 \mathrm{t}$ [5]. Experts, however, agree that the road to all ships having electric drives is still very long.

\subsection{Electric drives in air traffic}

The airplane industry is working intensively on the development of quieter, more economical and more environmentally friendly planes. That is why the interest of the industry for the electric powered airplanes is getting bigger and bigger [6]. The best chances are given to the hybrid drive, as the combination of the jet engine and the electric engine. Turbine of the jet engine charges the battery through the generator, during a steady flight at the travel height. At the landing or the take-off of the plane, additional power of the electric engine is used, which reduces airplane noise. The biggest problem here is also the weight of the necessary batteries, because the energy capacity of the fossil fuels (kerosene) is 60 to 100 times greater than the energy capacity of the best batteries today. It is not expected for smaller planes with hybrid drives to take-off and fly in the next 15 years. Bigger airplanes are going to take considerably more time. The hybrid aircrafts are expected to reduce the fuel consumption by $30 \%$ until 2035 and by $75 \%$ by 2050 .

\section{A VIEW INTO THE FUTURE}

Less than $2 \%$ of today's 1.38 billion vehicles (947 millions of passenger vehicles and 335 millions of commercial vehicles) do not have gasoline or diesel engines, Figure 9. Most of the cars that do not use these two fuels have IC engines that use natural gas (methane) or liquid petrol gas (propane) or so-called bio-fuels (ethanol, vegetable oils). Although the number of the electric vehicles and vehicles with hybrid drives does not exceed $0.12 \%$ of the total number of vehicles in the world today, these vehicles are mentioned more in public discussions than all others, as if only they are expected to solve all the problems in the transport. 


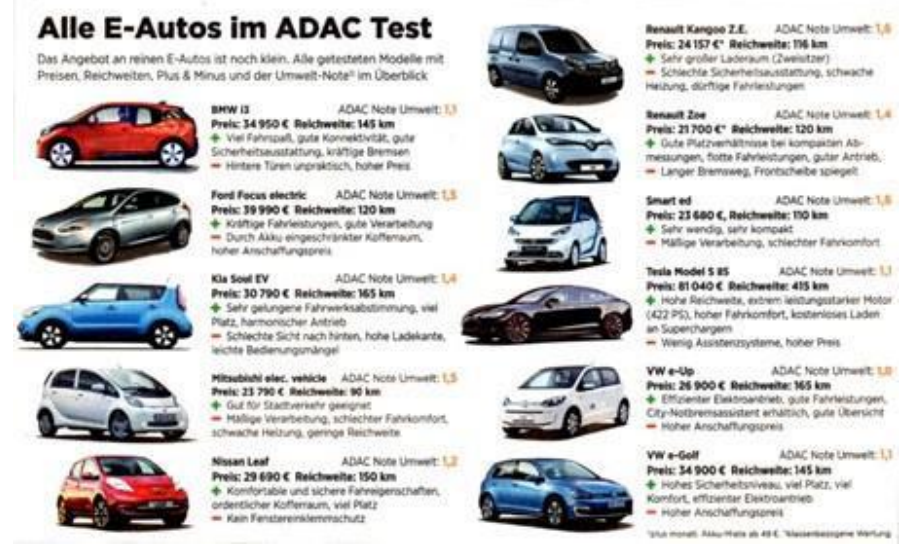

Figure 9. Modern electric cars (source: ADAC)

Whether the new attempt at introducing electric drives is to be successful, unfortunately, does not only depend on the economic parameters that accompany this vehicle, but also on the political decisions of the governments. The German Government has reached the decision that the number of registered passenger cars with electric drives must be at least 1 million until 2020. Implementation of this decision would mean that, as of today, more than 20,000 electric or hybrid cars must be sold per month, which is far from the actual sales, which is 10 to 15 times lower. What is interesting is that only about $15 \%$ of the registered electrical cars in Germany is in private ownership. The largest part is found in larger companies (e.g. post offices) or in the shop windows of the shopping centers.

\subsection{Fuel cells}

The biggest drawback of electric vehicles - a small energy capacity of the batteries, has found the solution in part through the so-called hybrid drive, where optimised IC engine is applied to drive electric generators. As the IC engine also produces unwanted emissions of carbon monoxide $(\mathrm{CO})$, carbon dioxide $\left(\mathrm{CO}_{2}\right)$, nitrogen oxides $\left(\mathrm{NO}_{\mathrm{x}}\right)$, unburnt hydrocarbons (HC) and particulate matter (PM), during its operation, there are proposals to replace the IC engine with so-called fuel cell. A fuel cell, whose working principle was patented by Englishman William Robert Grove back in 1839, operates on reverse electrolysis principle, Figure 10. While, in the process of electrolysis, water dissolves into hydrogen $\left(\mathrm{H}_{2}\right)$ and oxygen $\left(\mathrm{O}_{2}\right)$ with the help of electricity, in the fuel cell, hydrogen combines with oxygen, so the electric power, the heat and the water vapour $\left(\mathrm{H}_{2} \mathrm{O}\right)$ are produced. The electric power is used either directly to drive the electric engine of the vehicle or to charge the batteries. 


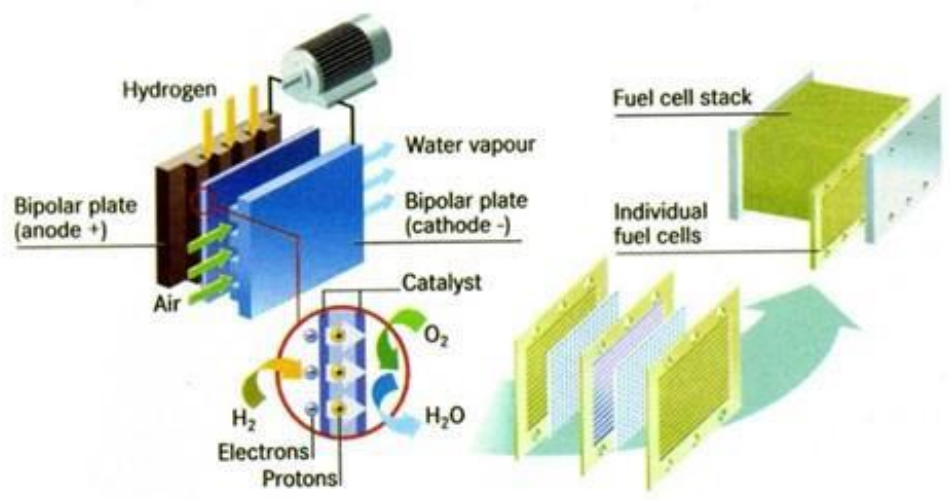

Figure 10. Energy from air and hydrogen: the principle of the fuel cell

Until now, hydrogen (H2) is the only fuel that allows the operation of fuel cells for cars. Although the forecasts for fuel cells were very optimistic at the beginning of this century, this drive so far has not asserted itself on the world market. The only market vehicle with the fuel cell is Toyota-Mirai, Figure 11.

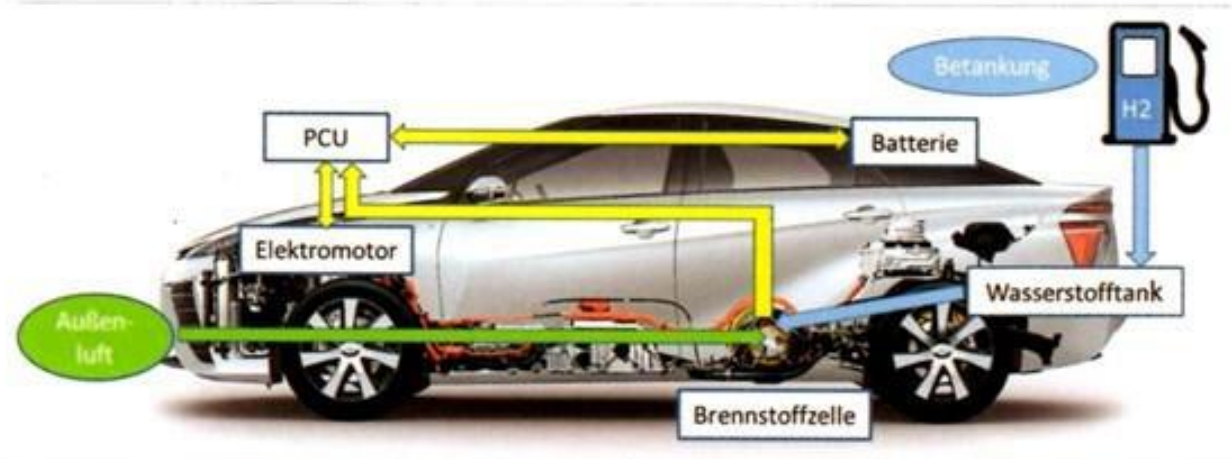

Figure 11. Toyota Mirai with fuel cell

Many believe that, with the development of the battery for the accumulation of electricity, the fuel cells become redundant, because, in order to obtain hydrogen (theoretically the best way is by electrolysis of water), a large amount of electric power is needed. The biggest problems with hydrogen are with its storage, transport, or the absence of entire infrastructure. In the fuel cell, the hydrogen is then used as a source for the production of electricity. The question is why the power would not be directly used for charging the battery, instead through the hydrogen or the fuel cell. One of the leading companies in the field of fuel cells, the Daimler, has moved the focus of the research from the fuel cells to the development of batteries for the accumulation of electrical energy [7]. It is often said that the fuel cells do not have a negative impact on the human environment, because they do not emit other harmful substances beside water vapour $\left(\mathrm{H}_{2} \mathrm{O}\right)$. Today, the hydrogen, which is mainly used for industrial purposes, is almost exclusively (96\%) produced from fossil fuels (natural gas, petroleum, stone coal) with the releasing of the large amounts of $\mathrm{CO}_{2}$. Carbon dioxide $\left(\mathrm{CO}_{2}\right)$ is almost exclusively mentioned during the discussion about the effects of 
greenhouse gases on the climate change. It is forgotten that the water vapour $\left(\mathrm{H}_{2} \mathrm{O}\right)$ has the greatest share in the natural greenhouse effect and thus has a threefold greater influence on that effect than carbon dioxide. There is no thought yet about the effect the water vapor will have on the environment if all the vehicles were to transfer from fossil fuels to hydrogen.

\subsection{E-(ecological) fuels}

In parallel with the intense work on the development of electric drives for vehicles, the automotive industry is also working on the further development of the IC engine and, together with the oil industry, also on the development of new, ecologically better fuels. Above all, they include liquid fuels (alcohols, vegetable oils) that are obtained from renewable sources or from the waste. These fuels have the advantage that they can immediately be applied on the existing vehicles, as well as use the existing infrastructure. Hydrogen is also an ecological fuel, which is very good fuel for IC engines and the engines that can successfully consume it were developed a long time ago.

\section{CONCLUSIONS}

Writing this paper in Detroit, one of the centres of the world automotive industry and observing the daily traffic of thousands of cars with which the workers travel from their homes to work and back, and looking at the dimensions of this continent, I wonder how long will it take for this traffic to cross to the electric drive. From the aspect of densely populated European cities, the discussions about the electric cars have an entirely different dimension, than on this continent. Probably, it is similar in Russia (Siberia is also Russian land), Brazil, India, Australia, China... Well-built infrastructure for recharging the batteries is considered as one of the key issues for the success of the electric cars, in addition to their price. The developing countries will not be able to build this infrastructure and will be related to IC engines for a long time. Wealthier people in the USA are buying the car, which bears the name of the famous scientist, Tesla, showing their commitment to the conservation of nature. There is no mention of the fact that their private, heated swimming pools, the air conditions in their villas, numerous electrical and electronic devices with continuously turned on stand-by lights, boats and ships, consume more energy and emit more $\mathrm{CO}_{2}$ than their cars with IC engines. All of the world's cars and commercial vehicles transport is responsible for less than $13 \%$ of the total anthropogenic (i.e. of man created) $\mathrm{CO}_{2}$ emissions. The largest source of these emissions are electric power plants for electricity generation, whose share ranges from $25 \%$ to $40 \%$ [10]. Behaviour of the countries -producers of oil has considerable effect on the success of the electric drive in the large series production. Lowering the price of oil, whenever there was a danger of its replacement, has eliminated all the efforts for the development of alternative powertrains and alternative fuels. The conclusion of this analysis of electric drives for motor vehicles, can only state the same as it repeats for over half a century: "The piston IC engines will be substituted by the better powertrains during the following 10 to 15 years and the existing oil reserves will be spent in the next 30 to 40 years!"

\section{REFERENCES}

[1] "Die Geschichte der Elektromobilität", Ferrytells Verlags und Beratungs GmbH, Vienna, 2017.

[2] Angermaier, A. et al.: "E-Drive: Affordable-Further-Faster", 38th International Vienna Motor Symposium, 2017. 
[3] Winter, M., Friesen, A., Schappacher, F.M.: „Lithium-Ionen-Batterien: Stand der Technik in Performanz und Sicherheit", 38. Internationales Wiener Motorensymposium, Vienna, April, 27th-28th, 2017.

[4] Scheider, W. H.: „Effiziente Verbrennungsmotoren und elektrische Antriebe der Zukunft: Der Beitrag von Mahle", 38. Interantionales Wiener Motorensymposium, Vienna, April, 27th-28th, 2017.

[5] Von Dierk, J.: "Elektrisch übers Wasser", VDI-Nachrichten, April, 28th, 2017.

[6] "How electric aircraft could change aviation?", SAE-Europe, 2017.

[7] "Brennstoffzelle für Daimler out", VDI-Nachrichten, No. 17, April, 28th, 2017.

[8] Hatz, W.: "Porsche 919 Hybrid - Le Mans. The Future of the Sportcar", 36th International Vienna Motor Symposium, Vienna, 2016.

[9] ACEA: "Alternative Powertrain”, ACEA, Brussels, May, 4th, 2017.

[10] Gruden, D.: "Umweltschutz in der Automobilindustrie". Vieweg+Teubner Verlag, Visbaden, 2008. 